\title{
レーザースポット
}

\section{新式内燃機 関*}

\author{
エドワード・テラー** \\ (カリフォルニヤ大学ローレンスリバモア研究所)
}

今日私がお話ししようとすることはどちらか と言えば単純なことである。事実非常に簡単な ことなので，多くの数式を用いるまでもなく， 概念的なことだけを述べる。実際私が述べる内 容は専門家にとってはすべてよく知られたこと であり，何も新らしいことはないけれども広く 議論をまきおこし，さらにその輪を広げて実り あるものにできれば幸いである。

まず私は圧縮について述べたい。そこには非 常に簡単な法測，すなわち相似例が存在する。 これは厳密な意味では正しくないけれども良い 近似を与えるもので実際的であると言える。相 似則というのは定量的には, 同じ過程と同じ効 果を得ようとする場合圧縮が大きい程必要な材 料,したがって必要なエネルギーは小さくてす むということを意味している。

これが modern 'internal combustion engine' の秘密である。もちろんここで私は自動車のこ とを言っているのではない。水素爆弾を, 八イ オクタンの重水素-三重水素 (D-T) 混合物 (DT は液体の密度とする）を用いて作るのではなく， 液体を1000倍に圧縮するということについて話 をしているのである。（私はここで 1000 倍とい う数字に固執したい。なぜなら三重根が簡単な 数字になるからである。)したがってまず直径 1 $\mathrm{mm}$ の液体 D T の小滴を考えよう。これを一次元 的に10倍に圧縮して密度を1000倍に増大させる。 液体のD T 混合物を動作させるのと同じ設備で これを働かせるためには粒子 1 個あたりのエネ ルギ，速度および膨張が等しくなるように考え なければならない。 D T 反応で重要な 2 体衡突 は $\alpha$ 粒子と中性子を生成する過程であるが, こ の場合衝突時間は（密度が高いため）1/1000に
なる。これは時間スケールを1/1000に縮少しな ければならないことを意味している。もし膨張 に対しても同様の状況を得たいなら, 空間スケ ールも1/1000にしなければならない。

さて我々は $10^{-1} \mathrm{~cm}$ のきさから出発し, $10^{-2}$ $\mathrm{cm}$ に圧縮した。これが動作流体である。これは 直径にして1000倍大きいD T の質量を動作させ るのと同じことである。（なぜなら時間，空間 スケールをこの割合で変化させる必要があるか らである。）すなわち直径 $10 \mathrm{~cm}$ の D T に対応す る。したがって体積は $10^{9}$ 倍である。しかしな がら質量は $10^{6}$ 倍である。というのは密度の比 が $10^{3}$ であるからである。それ故, 一般に密度 をある比率で変化させると質量はその比の 2 乗 で減少することになる。密度における比率 1000 は質量での比率 $10^{6}$ を意味している。我々はそ こでinternal combustion engineを可能にす る微小な爆発を期待する。短時間でそのなりゆ きを調べてみる。

しかしながら私がまずいいたいことは相似側 が厳密な意味では正しくないということである。 これには大きな理由が2つある。1つは全く重

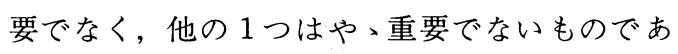
る。

全く重要でない理由は 2 体衝突過程を考えな ければならないことである。2体衡突は遠距離 的な作用であって, シールド効果が重要となる。 よく知られた近似公式では対数項があらわれる。 この対数項は相似則には従わないが, 条件にす ごく敏感ではない。ある場合にはこのファクタ が10であることもあるし，20のこともある。た だ全体としての変化は大して重要ではない。

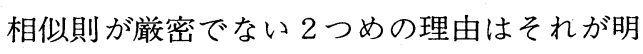

* 第 7 回量子エレクトロニクス国際会議（1972年 5 月モントリオール）における特別講演の録音テープ

** 井沢靖和 訳 
きらかに 3 体衝突には適用できないことである。 我々は 2 体衡突に対してうまくあてはまるよう に相似則を考えてきたが密度が高くなると 3 体 衝突がより重要となる。事実考慮すべき 3 体衝 突が 1 つる。すなわち光子，電子，原子核の 衝突により光子が吸収される過程である。逆の 過程すなわち電子と原子核の衝突による光子の 放出は 2 体衝突であって相似則に従う。しかし 吸収過程はそうではない。

この修正は熱核反応流体の温度が $1 \mathrm{keV（1}$ $\left.\mathrm{M}^{\circ} \mathrm{K}\right)$ 以下のところで重要となる。 $\mathrm{kV}$ 以下で は吸収が問題となる程強く, 高密度の燃料は相 似則で考えてきたよりももっとよく反応するで あろう。しかしながら $1 \mathrm{keV}$ という温度はひど く興味をそ〉る程の温度ではない。本当に興味 ある温度は 4 $5 \mathrm{keV}$ であってそこでは吸収の 影響は比較的小さくなる。

ここで私は次のことを問いかけたい。我々が 実用として考えている大きさでは高密度で動作 させるのがよいのかそれとも低密度がよいのか と。私はこの問題にレーザーの観点からとりく んでみたい。（それはここがレーザーに関する 会議の場であるという理由からだけではない） なぜなら我々は，モスクワからの同僚が少し前 に示したように, レーザーを用いて熱核反応燃 料にまわりからエネルギを集中し，それを圧縮 しようと考えているからである。圧縮に必要な 程の巨大なエネルギーをレーザー光の形で作り だすことは容易なことではないし，ピコ秒をそ れ程こえない時間内にそれだけのエネルギを生 成するのはむしろ困難といってよい。しかし液 滴近傍で利用できるエネルギを得るためにはこ れが必要である。

この結果今一つの問いかけが必要である。 最小エネルギですむ圧縮とは何か？」答は圧縮 が大きければ大きい程, 必要な質量およびエネ ルギは少なくてすむことである。状態方程式を 考えよう。圧力は $\rho^{\gamma}$ に比例する。 $\gamma$ は 3 以下で ある。（高圧縮下では $\gamma$ は $5 / 3$ となる）。必要な エネルギは $\rho^{\gamma-3}$ に低下することは容易にわかる。 事実 $\rho^{-2}$ の寄与は必要な質量が $\rho^{-2}$ によって 減 少することにより， $\rho^{\gamma-1}$ は単純な圧縮によるも のである。我々が考えている状況では $\gamma$ は $5 / 3$
であり, $\rho^{\gamma-3}$ は $\rho^{-3 / 4}$ となる。 $\rho$ が大になれば なる程必要なエネルギは減少する。

どうして私はこんな控え目な見積をしている のか，なぜ1000倍の圧縮を考え $10^{6}$ 倍を考えな いのか。後者の方がよいことはいうまでもない。 しかし液滴を対称に圧縮し，しかもくだかぬ うにすることは少々困難である。

ついでながらある理由（最も大きなものは私 にはわからないという理由）から，どのように して圧縮を行ない, またどのようにして液滴に エネルギを注入するかについての詳細を述べる のは差し控える。この後午後の講演で私の同僚 がそのうちのいくつかをお話しするであろう。 彼等も最後の 3 つの講演を聞いてほしいと言つ ている。あなた方の友人にも来聴をお願いした い。これはコマーシャルが過ぎました。

さてここで取り扱うべき質量を決定するいく つかの要因について述べてみたい。もちろん用 いる質量が少なければ少ない程よいことはいう までもない。しかし質量があまり小さいと $2 つ$ の困難に入りこむことになる。1つは充分な燃 焼がおこる前に膨脹が生じることである。他の $1 つ$ 熱核反応によって放出されるエネルギが 液滴にとどまらないことである。そこでしばら くターゲットのエネルギバランスについて少し 述べなければならない。

まず第 1 に膨張のエネルギを考えていない。

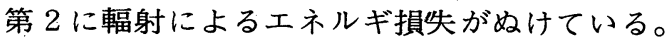
高圧縮下では輻射のうちには再吸収されるもの もあるが，考えている領域はそれ程大きくない。 生成エネルギは損失を上まわらねばならない。 ついでながら輻射損はごく簡単に計算できる。 しかしこれらはすべて最小の大きさを決定しよ うという議論から見ればごく一部にすぎない。

もう一つのポイントは生成された粒子の工ネ ルギーが標的内に蓄積されねばならないことで ある。このエネルギは D T反応では大部分が14 $\mathrm{MeV}$ の中性子に与えられる。これらはほとんど すべてのエネルギを保持したま、逃げだしてし まう。 $4 \mathrm{MeV}$ 以下のごく少量のものが $\alpha$ 粒子に 与えられる。これはターゲットにとどまると考 えるかもしれない。しかしことはそれほど単純 ではない。エネルギの大きい $\alpha$ 粒子はそのエネ 
ルギを低温の電子に与えると考えられる。しか し電子は質量が小さいため, $(\mathrm{MeV}$ でなく $\mathrm{keV})$ 程度の比較的低温であっても非常に速く運 動している。遅い粒子から速い粒子へエネルギ が伝達されるというのは不自然である。少なく とも 1 次近似では正しい式を導ける。ただし $\alpha$ 粒子が, それ自身よりも遅い電子と相互作用し た場合に通常のエネルギ損失がおこるとする。 Maxwell 分布をもった電子は, 大部分が $\alpha$ 粒子 よりも速く動き, したがって正味のエネルギー 伝達には関与しない。これはオーダーとしては 正しいものでもっともらしいと考えてよい。

ついでながらこのような考察はすべて制御熱 核反応の研究では再三重要となってくる。我々 が今考えてきた試みでも非常に重要となってき たし，磁場により閉じこめられたプラズマにお いてもなされていることである。平衡時間はこ れらの要因に依存するもので, この場合にも非常 に重要である。というのはレーザーで標的を加 熱するとき 1 次近似ではまず電子が加熱される。 電子からイオンへのエネルギ伝達には時間がか かり，この時間を無視するわけにはいかない。

さて話をもどして圧縮の問題に関連した困難 さに関心を向けよう。エネルギをターゲットに 注入するには多くの方法がある。事実レーザー 光ォこの小さいターゲットに集中するとき, 光 の電界は水素原子の電子が運動している場での 電界よりも大きくなり直接電離が生じる。この ような強電界中での現象は完全には理解されて おらず，私にとっては確かにそうである。もっ と多くの研究が必要である。結局このような高 電界中では現象はもっと単純なものであるとい うことになる可能性もある。

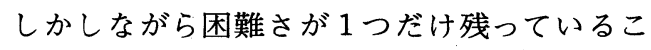
とを予告しておきたい。光が生成されたプラズ マに入射したとき, 電子と原子核は逆方向に加 速される。電子は同相で運動する。加熱の一つ の過程は非線形の不安定性である。電子の運動 に乱れが生じる。しかしこの乱れは最初は完全 ではない。電子の大部分はまだ一諸に, しかも 多分高䧓波で運動している。この時これら電子 はコヒーレントで強力な光を放出する。標的の まわりでプラズマの密度はそれほど濃くなく，
平衡状態ではエネルギはほとんど輻射として放 出される。エネルギー損失としては輻射が重要 である。

さて圧縮が起り, 熱核反応が生じたと仮定し よう。エンジンを得ることを考えよう, 我々に 何ができるか。internal combustion engineに より数 100M Wの発電所を作れるであろう。燃 料は常に充分にある。エネルギー生成としては きれいで非常に安全なものである。

まだ技術的には困難さは残っている。これに ついて述べよう。

私が耳にしている一つの意見では，毎秒 100 回の爆発を起こさせる。この場合毎秒 100回レ 一ザー光により照射されるターゲットは必らず しも同じ位置にある必要はない。また爆発する プラズマを閉じこめるつもりはない。そうしよ うとする人はいるかもしれないが, それは少々 困難である。できるだけ単純な形にして，逃げ だしてくる中性子を利用すれば良い。しかし夕 ーゲットをレーザー光の焦点内に保持しておく のはもっと困難である。さらに容器は毎秒 100 回の爆発に耐えるものでなければならない。こ の爆発は数ポンドの T N T 火薬に相当する。装 置の寿命は 100 億回の爆発程度にしなければな らない。これは簡単だといえるものではない。

もう一度試みてみよう。他の極端な例は $10^{17}$ erg の爆発を利用することである。これは T N

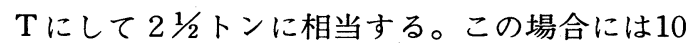
秒に 1 回の割で爆発を引きおこせば良い。容器 は数千万回の爆発に耐えれば良い。技術的には まだ問題がある。

私の同僚を大変失望させることになるかもし れないが，私は，私が天国へ行く前にあるいは それ程早い時期にはこれがうまくいくとは期待 していない。何か別の形でならもっと早く実現 するものがあるかもしれないと思う。これは少 々気まぐれと思われるかもしれないが, それはこ の internal combustion engineを宇宙空間の 推進用として用いることである（私はこの可能 性に向って非常に興味ある研究がLos Alamos で行なわれていることを知っている）もし温度 が $10 \mathrm{keV}\left(100 \mathrm{M}^{\circ} \mathrm{K}\right)$ 近傍で熱核反応を発生で きれば，プラズマの膨張速度は $10^{8} \mathrm{~cm} / \mathrm{s}$ 程度と 
となる。これは技術者流の馬鹿な言葉でいうな ら比推力が $10^{5}$ であることを意味している。

もし容器を光速の $1 / 1000$ に加速する積 りなら数 $100 \mathrm{MW}$ のエンジンで数日中に達成出 来るであろう。そうなると 1 週間で火星へ到達 できる。往復で 2 週間である。宇宙船は中性子 に対し厳重なシールドをほどこさなければなら ない。熱廃棄の問題が重大であるし,レーザー を駆動するに必要なエネルギーの取り出しにつ いても問題が残っている。

後者については私はあまり心配していない。 なぜならプラズマの流れを規制する磁場が生じ ると予想されるからである。この磁場は爆発に よりパルス的に発生するもので，電流を誘起す る。ついでこの電流がレーザーを駆動する。 実際問題として廃棄すべき熱量はほんの一部に すぎないが熱廃車の問題は重大である。私は

Los Alamosでもやっと光速の 1/3000の速度 までを保証しているにすぎないことを告白した い。ただ彼等のいっていることは，もっと控え 目であるが，可能性はより大きいと思う。

発電所について述べる前に宇宙推進について 話すのは狂気のさたではないのか? 私は断固と してそうではないと断言する。馬鹿げているの

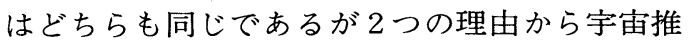
進の方がより容易であると言える。この場合装 置は非常に短時間だけ動作すれば良いし，また 地上で経済的にパワーを取りだす何らかの仕事 をしようとする場合の数1000倍の予算も仕事も 与えられよう。したがって私は宇宙船がこの種 の internal combustion engineを今世紀利用 しうる最大の好機であると言える。

この仕事は国際的に力を結集し, 試みてほし いということを私は最大限に強調したい。胸襟 を開き一致協力することこそ正しい道である。

多くの人が持っていると思われる疑問につい て議論して私の話をしめくくろう。もしまだ現 実の装置がないなら, 実物が得られ，また熱核 反応が有効におこっている証明が得られるのは いつか? 私はこれに答えるつもりはないが, 悲 観論者と楽観論者についての私自身の定義を示 したい。悲観論者というのは常に正しいが，そ れを楽しめない人である。楽観論者は, 未来は
不定であると考えている人である。利は楽観論 者にある。私は楽観論者になりたいと思うし， このデモンストレーションが1970年代のある時 期それもおそらく1970年代の早いうちに成功す るものと信じたい。

質問 どのような種類のレーザーを用いますか。

答 どのような種類のレーザーを用いるか との質問ですが私にはわからない。第 1 にあげ られるのはガラスレーザーだと思う。これだと 最小 $10000 \mathrm{~J}$ が必要であろう。 Nd ガラスレーザ は野球場の一畦側にいる。 $\mathrm{CO}_{2}$ レーザーに対する 望みも萧ててはいないがあなた方の中にはどち らがよいかという考えをもっている人がいるに ちがいないと私は思う。

質問 圧縮についてもう少し話していただけ ませんか

答 圧縮についてはすでにお話しした簡単 なこと以外に議論するつもりはない。すなわち エネルギーは吸収あるいは不安定性によって規 則正しい運動をしている電子に引き渡され，そ れが非常に短時間内に変換される。私が先程コ マーシャルした論文はこれについて取り扱って いる。他にもそのような論文はあると確信して いる。私が先に述べることは悪いでしょう。こ こにいてその講演を聞きましょう。

質問 もっと高圧縮ではD-D反応を利用する 方が有利ではないか。

答 もっと圧縮を大きくすればD-D反応を 利用することは可能である。私はそれを用いる つもりはない。高圧縮下でも D-T 反応を利用し て量を小さくしたい。というのは私が今述べて きた個々の爆発でも大きくて不便である。三重 水素が高価であるのは事実である。しかし D$\mathrm{T}$ 反応では高速の中性子が生成されそれがリチ ウムに衝突して三重水素を作る。少なくとも消 費分は再生産される。リチウムは豊富であり, それゆえ D-T 反応以外のものを考える大きな理 由は私にはない。これで充分でしょう。

質問 国際的な協力というのはあなたの述べ られなかった技術的問題の一つですか。

答いや私はそれについてお話した。とこ ろで国際協力は技術的問題ではない。私は 
“human engineering” といった表現を排斥す る。これらの2つの単語はここでは一諸に使え ない。技術的な問題というのは種々の過程, 多 くは論理的なもの, を経て解決できる。それに
対して人的な問題はしばしば非論理的な過程を 経て正しく解決される。それ以上は私の分野外 のことである。議長, 降壇してよろしいか? 